\title{
KETERAMPILAN MANAJERIAL KEPALA SEKOLAH DALAM IMPLEMENTASI PENDIDIKAN KARAKTER DI SD AL-AZHAR KELAPA GADING SURABAYA
}

\author{
Dimas Kurnia Robby \\ Pascasarjana Program Studi Manajemen Pendidikan Universitas Negeri Surabaya \\ dimasrobby@mhs.unesa.ac.id
}

\begin{abstract}
Abstrak: Penelitian ini bertujuan untuk mendeskripsikan peran keterampilan manajerial kepala sekolah SD Al-Azhar Kelapa Gading Surabaya dalam mengelola program pendidikan karakter yang menjadi andalan di lingkungan Yayasan Al-Azhar Kelapa Gading. Fokus keterampilan manajerial dalam penelitian ini adalah keterampilan konseptual, keterampilan teknis dan keterampilan hubungan manusia. Penelitian ini menggunakan pendekatan kualitatif deskriptif dengan desain penelitian studi kasus, teknik pengumpulan data dengan menggunakan observasi, wawancara dan dokumentasi dengan narasumber kepala sekolah, guru pimpinan yayasan dan orang tua siswa. Hasil penelitian menunjukan bahwa peran keterampilan konseptual kepala sekolah ditunjukan dalam kemampuan kepala sekolah yang mampu membagi peran baik sebagai pimpinan yayasan maupun sebagai kepala sekolah dan membagi konsep program pendidikan karakter sesuai jenjang pendidikan di yayasan Al-Azhar, lalu kepala sekolah memiliki kemampuan untuk memandang ke depan tentang bagaimana manfaat dan hambatan program pendidikan karakter. Dalam peran keterampilan teknis kepala sekolah menunjukan bahwa kepala sekolah SD Al-Azhar Kelapa Gading Surabaya terampil dalam memanfaatkan teknologi, sarana dan prasarana serta memberikan kesempatan pertemuan dengan tenaga pendidik dan tenaga kependidikan seminggu sekali. Selain itu, kepala sekolah SD Al-Azhar Kelapa Gading Surabaya juga tidak segan untuk turun ke lapangan untuk memberikan contoh perilaku baik. Dalam keterampilan hubungan manusia kepala sekolah SD Al-Azhar Kelapa Gading Surabaya terermin dalam cara bergaul dan berkomunikasi kepada tenaga pendidik maupun tenaga kependidikan, selain itu kepala sekolah juga terampil dalam memberikan motivasi yang menggugah semangat agar tidak lelah memberikan penanaman karakter pada peserta didik.
\end{abstract}

Kata kunci: Keterampilan manajerial,kepala sekolah, pendidikan karakter.

Abstract: The purpose of this study was to discover the influence of motivation and rewards towards teacher's commitment at Yayasan Ittiqon Kapuk Muara. This research is using a quantitative approach in which the sampling method is using total sampling that spread questioners to all 74 teachers. The result of this research shows that motivation and reward is positively influenced teacher's commitment. The findings suggested that school principal should be more initiative to embrace all teachers to keep teacher's loyalty at school or foundation, for the school to keep or even rising commitment, to give more motivation both intrinsic and extrinsic by giving training and rising incentive to all teachers, and to other researchers who wants to do the same research to add another factor that seemed can influenced teacher's commitment.

Keywords: motivation, rewards, teacher's commitment.

Penerapan Pendidikan karakter merupakan salah satu model pendidikan yang dimaksudkan untuk dapat meningkatkan kualitas sumber daya manusia di Indonesia agar mampu bersaing dalam pasar global. Menurut Mustari (2014: 10) terdapat 5 ranah pendidikan yang dapat menumbuhkan karakter yang baik, yaitu: keluarga, diri 
sendiri, pemerintah, sekolah, lingkungan dan masyarakat. Oleh sebab itu, pendidikan karakter diharapkan oleh pemerintah agar dapat diterapkan oleh semua satuan pendidikan di sekolah sesuai amanat Undang-Undang Sistem pendidikan Nasional No 20 tahun 2003 Bab II pasal 3.

Menurut Rivai (Utami, 2012: 3) mengungkapkan keberhasilan penyelenggaraan pendidikan ditentukan oleh tersedianya manajer pendidikan yang handal. Tanpa manjer yang handal akan banyak lembaga pendiidkan yang gulung tikar karena tidak berhasil memuaskan stakeholder. Oleh karena itu dalam melaksanakan amanat pemerintah untuk keberhasilan penanaman pendidikan karakter di sekolah, kepala sekolah diharapkan dapat mampu menguasai keterampilan manajerial untuk mendukung tugas dan fungsinya. namun, dalam prakteknya di lapangan tidak semua sekolah sanggup memenuhi tuntutan pemerintah dalam melaksanakan penanaman program pendidikan karakter.

Untuk itu, sebagai seorang manajer, kepala sekolah harus mau dan mempu mendayagunakan seluruh sumber daya sekolah dalam mewujdukan visi, misi, dan mencapai tujuan (Mulyasa, 2003: 103). Untuk dapat memanajemen sumber daya sekolah dengan maksimal, menurut Pidarta(2004: 208) diperlukan tiga macam keterampilan manjerial yaitu: keterampilan konsep, keterampilan manusiawi, dan keterampilan teknik.

Wahjosumidjo

(2001:

mengungkapkan praktek manajerial yang termasuk dalam keterampilan konsep adalah: 1) kemampuan analisis, 2) kemampuan berfikir rasional, 3) ahli/cakap dalam berbagai macam konsepsi, 4) mampu menganalisis berbagai kejadian dan mampu memahami berbagai kecenderungan sosial, 5) mampu mengantisipasi perintah, 6) mampu mengenali macam-macam kesempatan dan problematika sosial. Sedangkan keterampilan teknik meliputi 1) menguasai pengetahuan tentang metode, proses, prosedur, dan teknik melaksanakan kegiatan khusus dan 2) kemampuan memanfaatkan serta mendayagunakan saran dan peralatan yang diperlukan dalam mendukung kegiatan yang bersifat khusus tersebut. Lalu, Perilaku hubungan manusia yang dilakukan oleh kepala sekolah menurut Wahyudi (2009: 78) adalah keterampilan yang meliputi: 1) menjalin hubungan kerjasama dengan guru, 2) menjalin komuikasi dengan guru, agar program sekolah dapat dipahami guru, 3) memberikan bimbingan dan bantuan dalam menyelesaikan tugas guru, membangun semangat/moral guru, 5) memberikan pengharagaan kepada guru yang berprestasi, 6) menyelesaikan segala permasalahan di sekolah, 7) mengikutsertakan guru dalam merumuskan pengambilan keputusan. 8) menyelesaikan konflik di sekolah, 9) menghormati peraturan sekolah, 10) menciptakan ikim kompetitif yang sehat diantara guru.

Pendidikan karakter di Indonesia menurut Samani \& Hariyanto (2011: 2) sangat memerlukan perhatian yang serius dari semua kalangan dengan semakin meningkatnya permasalahan tawuran antarpelajar, tindakan mencontek, pemerasan/kekerasan (bullying), kecenderungan dominasi senior terhadap junior, penggunaan narkoba, korupsi, dan lain-lain.Berangkat dari fenomena yang terjadi, persoalan penanaman pendidikan karakter di sekolah merupakan sesuatu yang sangat penting dan layak untuk disegerakan. Mengacu pada Suyadi (2012: 4) yang mengatakan bahwa"Konsep pendidikan karakter harus mengambil posisi yang jelas, yaitu karakteristik seseorang dapat dibentuk melalaui pendidikan". Pada realitasnya, penerapan pendidikan karakter di masingmasing sekolah beragam bergantung pada kemampuan sekolah dan kultur budaya masyarakat setempat yang ingin ditanamkan sekolah pada lulusannya.Oleh karena itu, menarik untuk diteliti lebih lanjut adalah bagaimana peran keterampilan manajerial kepala sekolah SD Al-Azhar Kelapa Gading Surabaya dalam menjalankan pendidikan karakter yang menjadi keunggulan di 
lingkungan yayasan Al-Azhar Kelapa Gading Surabaya.

Hasil penelitian Hajon (2014) menunjukan bahwa dalam perjalanan program implementasi pendidikan karakter di lembaga sekolah perlu mendapatkan dukungan oleh berbagai pihak terkait untuk membentuk budaya sekolah dan lingkungan sekolah yang dapat menumbuhkan nilai-nilai karakter peserta didik. Dukungan tersebut tentunya tidak akan berjalan dengan baik tanpa keterampilan manajerial kepala sekolah yang baik.

SD Al-Azhar Kelapa Gading Surabaya adalah sekolah yang berada di bawah naungan Yayasan perguruan islam Al-Azhar Kelapa Gading yang berdiri sejak tahun 2002. SD Al-Azhar Kelapa Gading Surabayamemiliki keseriusan untuk menerapkan program pendidikan karakter. Empat pilar karakter yang di terapkan dan menjadi keunggulan di lingkungan sekolah Al-Azhar Kelapa Gading Surabaya adalah: 1) Rabbaniyah, 2) Insaniyah, 3) IImiyah, dan 4) Alamiyah. Pola penanaman pendidikan karakter yang ditanamkan oleh SD Al-Azhar Kelapa Gading diterapkan dalam budaya sekolah sehari-hari, pesan moral lisan maupun tulisan, pengawalan Character Building yang berbentuk buku anekdot dan pemantauan dengan guru pamong,lalu penerapan program konsep 4 pilar karakter Al-Azhar oleh kepala sekolah dalam setiap kegiatan sekolah merupakan proses penanaman pendidikan karakter yang menarik untuk diteliti lebih lanjut. Selain itu, dalam studi pendahuluan yang dilakukan peneliti data bahwa kepala sekolah SD AIAzhar Kelapa Gading Surabaya merangkap jabatan sebagai wakil direktur yayasan AlAzhar Kelapa Gading cabang Surabaya yang juga membawahi program pendidikan karkater pada jenjang KB/TK, SD dan SMP Al-Azhar Kelapa Gading Surabaya di satu komplek lingkungan perguruan yang sama.

Tujuan penelitian ini adalah untuk mendeskripsikan dan menganalisis keterampilan konseptual kepala sekolah dalam implementasi pendidikan karakter di SD Al-Azhar Kelapa Gading Surabaya, keterampilan teknis kepala sekolah dalam implementasi pendidikan karakter di SD AlAzhar Kelapa Gading Surabaya, dan keterampilan hubungan manusia kepala sekolah dalam implementasi pendidikan karakter di SD Al-Azhar Kelapa Gading Surabaya.

\section{Konsep Dasar Keterampilan Manajerial}

Keterampilan atau skill secara Bahasa dapat diartikan sebagai kemampuan, secara hafriah menurut Yulk (Yusak 2016: 12) dalam kaitannya dengan keterampilan manajerial adalah"kemampuan seseorang untuk melakukan berbagai jenis kegiatan kognitif atau diperlukan dengan satu cara yang efektif."Sedangkan Manajerial berasal dari kata manajer yang berarti sesoarng yang menjadi pimpinan dalam organisasi.Menurut Handoko (Faisal 2012: 15) menjelaskan bahwa "praktek manajerial adalah kegiatan yang dilakukan oleh manajer". Dalam dunia pendidikan, sekolah merupakan sebuah organisasi manajemen yang dipimpin oleh seorang kepala sekolah sebagai manajernya.

Siagian (Yusak, 2016: 12) mengatakan bahwa"keterampilan manajerial adalah keahlian menggerakan orang lain untuk bekerja dengan baik."Kepala sekolah sebagai manajer memerlukan keterampilan manajerial. Pidarta (2011: 208) mengemukakan tiga macam keterampilan manajerial kepala sekolah yaitu: 1) Keterampilan konsep, 2) Keterampilan hubungan manusia, dan 3) Keterampilan teknik.

Agar seorang kepala sekolah secara efektif dapat melaksanakan fungsinya sebagai manajer, kepala sekolah harus mampu mewujudkan sikap dan perilaku keseharian di organisasi dengan nilai-nilai yang terkandung di dalam ketiga keterampilan tersebut seperti yang dijelaskan oleh Faisal (2012: 39) yaitu: pertama, keterampilan teknis adalah menguasai pengetahuan tentang metode, proses, prosedur dan teknik untuk melaksanakan kegiatan khusus dan kemamouan untuk memanfaatkan serta mendayagunakan sarana, peralatan yang 
diperlukan dalam mendukung kegiatan yang bersifat khusus tersebut.

Kedua, keterampilan hubungan manusia adalah kemampuan untuk memahami perilaku manusia dan proses kerja sama, kemampuan untuk memahami isi hati, sikap, dan motif orang lain, kemampuan untuk berkomunikasi secara jelas dan efektif sehingga mampu menciptakan kerja sama yang efektif, kooperatif, praktis, dan diplomatis. Serta mampu berperilaku yang dapat diterima kemampuan untuk menciptakan dan membina hubungan baik, memahami dan mendorong orang lain sehingga mereka bekerja secara sukarela, tidak ada paksaan dan lebih produktif (working with people).

Ketiga, kemampuan konseptual adalah kemampuan mental untuk mengkoordinasikan dan memadukan semua kepentingan serta kegiatan organisasi. Dengan kata lain, kemampuan konseptual ini terkait dengan kemampuan untuk membuat konsep (working with ideas) tentang berbagai hal dalam lembaga yang dipimpinnya yaitu kemampuan berfikir rasional, cakap dalam berbagai macam konsepsi, mampu menganalisis berbagai kejadian serta mampu memahami berbagai kecenderungan, mampu mengantisipasi perintah, dan mampu mengenali dan memahami macam-macam masalah sosial.

\section{Konsep Dasar Pendidikan Karakter}

UNESCO (Rohman dan Amri, 2012: 3) menjabarkan pendidikan adalah komunikasi terorganisasi dan berkelanjutan yang dirancang untuk menumbuhkan belajar selanjutnya dalam UU No 20 tahun 2003 tentang Sistem pendidikan Nasional menyebutkan pendidikan merupakan usaha sadar dan terencana untuk mewujudkan suasana belajar dan proses pembelajaran agar peserta didik secara aktif mengembangkan potensi dirinya untuk memiliki kekuatan spiritual keagamaan, pengendalian diri, kepribadian, kecerdasan, akhlak mulia, serta keterampilan yang diperlukan dirinya, masyarakat, dan Negara. Oleh karena itu, pendidikan bukan merupakan proses yang instan, yang di dalamnya terdapat unsur-unsur manajemen yang harus diterapkan agar pendidikan dapat berjalan sesuai track yang diinginkan oleh semua kalangan.

Sedangkan pengertian karakter oleh Kementrian Pendidikan Nasional mendefinisikan karakter sebagai watak, tabiat, akhlak, atau kepribadian seseorang yang terbentuk dari hasil internalisasi berbagai kebijakan (virlues) yang diyakini dan digunakan sebagai landasan untuk cara pandang, berfikir, bersikap dan bertindak (Pengembangan Pendidikan budaya dan karakter bangsa, 2010: 3).Selanjutnya pendidikan karakter itu sendiri menurut Lickona (2013: 3) "character education is the deliberate effort to help people understand, care abaout, dan act upon core ethical values" yang artinya pendidikan karakter adalah upaya yang disengaja untuk membantu orang memahami, peduli dan bertindak berdasarkan nilai-nilai etika. Dari pengertian di atas dapat ditarik kesimpulan bahwa pendidikan karakter merupakan usaha sadar dan terencana dari seluruh elemen pendidikan, baik di masyarakat, sekolah, maupun tingkat kementrian pendidikan yang mengarah pada satu tujuan yaitu perbaikan dan penanaman nilai-nilai karakter, sifat, dan perilaku peserta didik yang dilakukan semenjak tingkat pendidikan dasar.

\section{Keterampilan Manajerial Dalam Implementasi Pendidikan Karakter}

Untuk mendukung program pendidikan karakter di sekolah, kepala sekolah harus menjadi ahli dalam memainkan peran manajerial secara luas dalam tugasnya sehari-hari. Sebagai seorang manajer kepala sekolah dituntut untuk memiliki keterampilan manajerial untuk dapat mengorganisasi segala macam sumber daya yang ada di sekolah untuk tujuan sekolah.

Yulk (2010: 69) mengatakan bahwa ada tiga macam level manajemen yang membutuhkan keterampilan (konseptual, teknikal, dan hubungan manusia) yang efektif. Hal tersebut digambarkan oleh Yulk dalam gambar di bawah ini. 


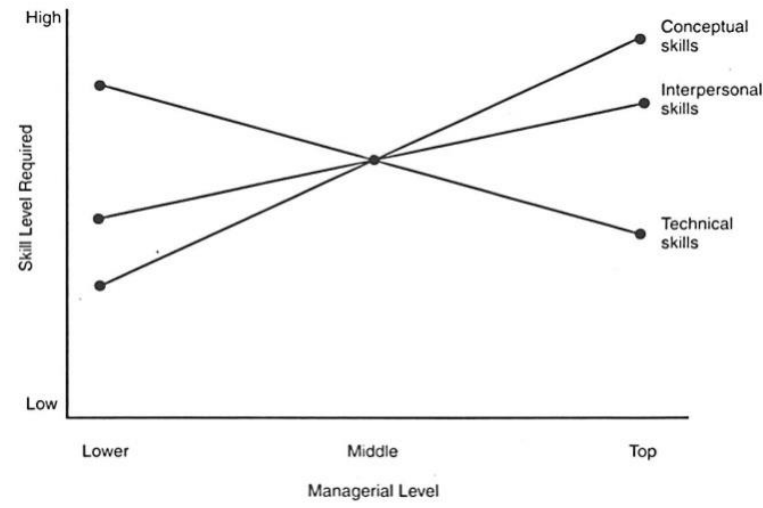

Gambar 1 Keterampilan manajerial yang dibutuhkan dalam setiap level manajemen yang berbeda Sumber: Yulk, 2010:69

Menurut Yulk, pada umumnya level manajemen yang tertinggi mempunyai variasi aktifitas yang harus dikoordinasikan. Manajer pada tingkat ini harus bisa mengantisipasi kejadian yang akan datang dan mampu membuat rencana untuk menghadapinya. Oleh karena itu kualitas strategi yang dibuat oleh manajer bergantung pada keterampilan konseptualnya namun tidak menampik pula manajer butuh keterampilan yang lain meski porsinya tidak sebanyak konseptual.

Sedangkan dalam middle management Yulk menjelaskan bahwa pada manajer tingkat ini keterampilan teknik relatif lebih penting daripada keterampilan konsep atau keterampilan hubungan manusia. Karena dalam level ini kemampuan teknik untuk mengimplementasikan kebijakan untuk pencapaian tujuan organisasi. Sedangkan untuk level manajer terbawah keterampilan hubungan manusia dibutuhkan untuk membangun hubungan dengan bawahan.

\section{a. Keterampilan Konseptual dalam Implementasi Pendidikan Karakter}

Pidarta (2011: 206) menjelaskan bahwa "pentingnya keterampilan konseptual sebagai keterampilan yang sangat dibutuhkan oleh para manajer puncak sehubungan dengan tugas utamanya yaitu menentukan strategi kebijakan mengkreasikan atau merencanakan sesuatu yang baru dan memutuskannya". Secara konseptual, penerapan pendidikan karakter dapat dilakukan oleh manajer melalui berbagai tahapan, salah satu proses tahapan pembentukan karakter di sekolah menurut Megawangi (Madrasah, 2015) adalah sebagai berikut: a) Moral Knowing. Menanamkan dengan baik pada anak tentang arti kebaikan. Mengapa harus berperilaku baik. Untuk apa berperilaku baik. Dan apa manfaat berperilaku baik, b) Moral Feeling. Membangun kecintaan berperilaku baik pada anak yang akan menjadi sumber energy anak untuk berperilaku baik. Membentuk akrakter adalah cara menumbuhkannya, c) Moral action. Bagaimana membuat pengetahuan moral menjadi tindakan nyata. Moral action ini merupakan outcome dari dua tahapan sebelumnya dan harus dilakukan berulangulang agar menjadi moral behavior.

\section{b. Keterampilan Teknis dalam Implementasi Pendidikan Karakter \\ Menurut Stonner, Manajer} membutuhkan keterampilan teknis yang cukup untuk melaksanakan suatu pekerjaan tertentu yang menjadi tanggung jawabnya, keterampilan teknikal adalah kemampuan untuk mengorganisir alat-alat, prosedur dan teknis suatu bidang khusus (Hidayatun, 2007: 31). Dalam hal mengorganisir sumber daya sekolah untuk mencapai tujuan, Handoko (Usman, 2011: 146) menjabarkan kegiatan fungsi pengorganisasian sebagai keterampilan teknik kepala sekolah sebagai berikut: 1) Penentuan sumber daya dan kegiatan yang dibutuhkan untuk mencapai tujuan organisasi, 2) Proses perancangan dan pengembangan suatu organisasi yang akan membawa hal-hal tersebut kearah tujuan, 3) Penugasan tanggung jawab tertentu, 4) Pendelegasian wewenang yang diperlukan kepada infividu-individu untuk melaksanakan tugasnya.

Zuhdiar (Budiastuti, 2010) berpendapat bahwa penerapan pendidikan karakter bagi siswa di skeolah bisa dilakukan melalui berbagai cara, dan disesuaikan dengan kondisi dan lingkungan di skeolah yang bersangkutan, penerapan pendidikan karakter di sekolah harus terintegrasi dengan kurikulum, meskipun setiap sekolah memiliki karakteristik dan potensi yang berbeda.

Berdasarkan uraian di atas dapat dipahami bahwa keterampilan teknis oleh 
kepala sekolah sebagai manajer dapat berfungsi sebagai kecakapan spesifik yang berhubungan dalam menganalisis hal-hal yang khusus terutama dalam hal penerapan pendidikan karakter ini yang tentu membutuhkan perhatian khusus secara teknisnya.

\section{c. Keterampilan Hubungan Manusia dalam Implementasi Pendidikan Karakter}

Pidarta (2011: 221) menjelaskan bahwa keterampilan kemanusiaan pada hakekatnya merupakan keterampilan untuk mengadakan kontak hubungan kerja sama secara optimal kepada orang-orang yang diajak bekerja dengan memperhatikan kodrat dan harkatnya sebagai manusia.Selanjutnya, ketermapilan hubungan manusia juga dapat tercermin di fungsi pengarahan dalam manajemen sekolah, beberapa tindakan yang dilakukan dalam menjalanakan fungsi pengarahan adalah berupa motivasi, ekuasaan, pengambilan keputusan, komunikasi, koordinasi, negosiasi, manajemen konflik, perubahan organisasi, ketrampilan interpersonal, membangun kepercayaan, penilaian kinerja, dan kepuasan kerja (Usman, 2011: 15)

Keterampilan hubungan Manusia oleh kepala sekolah di dalam penerapan pendidikan karakter di sekolah mutlak diperlukan agar sumber daya manusia di bawah organisasinya mau dan dapat dipimpin, mempunyai keinginan bekerja secara sukarela, termotivasi, tanpa perasaan dipaksa atau merasa terpaksa, mengembangkan kompetensinya dalam hal karakter, serta turut berperan aktif dalam implementasi pendidikan karakter di sekolah.

\section{METODE}

Penelitian ini menggunakan pendekatan deskriptif kualitatif untuk mendapatkan gambaran yang rinci dan hasil yang lebih mendalam berkaitan dengan keterampilan manajerial kepala sekolah dalam implemenetasi program pendidikan karakter.penelitian deskriptif kualitatif menurut Creswell (2012: 258) "mendefinisikan metode penelitian kualitatif sebagai prosedur penelitian yang menghasilkan data deskriptif berupa teks atau lisan dari orang-orang yang diteliti dan gambar yang memiliki langkah unik dalam analisis datanya."

Pola desain penelitian dalam penelitian ini menggunakan desain penelitian studi kasus, penelitian studi kasus menurut Creswell (2012: 343) menjelaskan "penelitian studi kasus strategi adalah penelitian yang dilakukan oleh peneliti untuk menyelidiki suatu program, peristiwa, aktiftas, proses, atau sekelompok individu secara cermat."

Keunikan kasus dalam penelitian ini seperti yang disebutkan di awal adalah adanya rangkap jabatan yang dijalani kepala sekolah SD Al-Azhar Kelapa Gading Surabaya dan Wakil Direktur Yayasan AlAzhar Kelapa Gading cabang Surabaya yang membawahi jenjang KB/TK, SD, dan SMP Al-Azhar Kelapa Gading Surabaya. selain itu, keunikan lainnya ialah pada program pendidikan karakter yang menjadi keseriusan SD Al-Azhar Kelapa Gading Surabaya sejak awal berdiri sehingga dapat berkelanjutan dan berkembang sampai saat ini dan bahkan pada awal-awal implementasi dari konsep pendidikan karakter ini berjalan sempat mendapatkan penghargaan sebagai sekolah percontohan konsep pendidikan karkater nasional.

Penelitian ini berlokasi di SD Al-Azhar Kelapa Gading Surabaya, subjek dalam penelitian ini ialah kepala sekolah, guru, pimpinan yayasan dan orang tua siswa. Penelitian ini menggunakan metode pengumpulan data dengan teknik wawancara, observasi, dan dokumentasi dengan melakukan kegiatan analisis data kondensasi, display data dan verifikasi.

\section{HASIL DAN PEMBAHASAN}

Salah satu program yang menjadi ciri khas di SD Al-Azhar Kelapa Gading Surabaya adalah program pendidikan karakter. Dengan 4 grand design karakter SD Islam Al-Azhar Kelapa Gading Surabaya yaitu Rabbaniyyah, Insaniyah, IImiah, dan Alamiah tentu membutuhkan kekuatan personalia sekolah yang solid untuk menjalankannya, kesolidan personalia di SD Islam Al-Azhar Kelapa Gading Surabaya juga pasti tidak lepas dari keterampilan 
manajerial kepala sekolah dalam memimpin SD Islam Al-Azhar Kelapa Gading Surabaya.

Temuan penelitian di SD Islam Al-Azhar Kelapa Gading Surabaya menunjukan bahwa kepala sekolah SD Islam Al-Azhar Kelapa Gading Surabaya dalam menjalankan tugas, fungsi dan perannya sebagai kepala sekolah terutama dalam menjalankan program pendidikan karakter telah berjalan dengan baik sesuai dengan konsep dan strategi sekolah yang telah dirancang bersama-sama. Hal tersebut sesuai dengan keahlian yang sesuai dengan ciri keterampilan manajerial yang dijabarkan Siagian (Yusak, 2016: 12) yaitu keterampilan menggerakkan orang lain untuk bekerja dengan baik.

\section{Keterampilan Konseptual Kepala Sekolah dalam Implementasi Pendidikan Karakter di SD Al-Azhar Kelapa Gading Surabaya}

Untuk mewujudkan tujuan dari program pendidikan karakter di SD Al-Azhar Kelapa Gading Surabaya tentunya telah diawali dengan berbagai perencanan dan pertimbangan yang matang. Selama proses tersebut berlangsung, berdasarkan hasil temuan penelitian di lapangan, kepala sekolah SD Al-Azhar Kelapa Gading Surabaya yang sekaligus menjabat sebagai wakil dari Yayasan Perguruan Islam AlAzhar Kelapa Gading di Surabaya telah melibatkan sumber daya manusia untuk merancang program pendidikan karakter di lingkungan sekolah dan di lingkungan rumah dengan membentuk tim konseptor pendidikan karakter.

Sesuai dengan pendapat Kurniadin (Muslim, 2015: 117) bahwa penggerakan merupakan upaya untuk menggerakkan atau mengarahkan tenaga kerja (man power) serta mendayagunakan fasilitas yang ada untuk melaksanakan pekerjaan bersama. Pendapat yang lain dikemukakan Faisal (2012: 39) yang mengatakan bahwa keterampilan konseptual adalah kemampuan mental untuk mengkoordinasi dan memadukan semua kepentingan serta kegiatan organisasi. Maka dapat dikatakan kepala sekolah telah menunjukan keterampilan konseptualnya dalam memimpin perencanaan dan selanjutnya pelaksanaan program pendidikan karakter

Bentuk keterampilan konseptual lain yang diaplikasikan dalam fungsi manajemen yaitu dalam pengorganisasian program dengan memberikan tugas lebih untuk mengawasi siswa agar terlaksananya tujuan pendidikan karkater, kepala sekolah SD AlAzhar Kelapa Gading Surabaya telah membuat konsep agenda rapat mingguan untuk membicarakan atau mengevaluasi pelaksanaan tugas dan fungsi selama seminggu bagi tenaga pendidik dan pertemuan untuk membicarakan berbagai hal yang berkaitan dengan program pendidikan karakter yang diselenggarakan setiap dua minggu sekali bagi tenaga pendidik, tenaga kependidikan maupun perwakilan orang tua. Artinya adalah kepala sekolah telah cukup terampil dalam memberikan konsep tugas kepada guru melalui suatu forum yang dimana menurut peneliti hal tersebut lebih mempermudah bagi individu yang ditunjuk karena mendapatkan pandangan, masukan dan motivasi yang lebih dari guru yang lain.

Selanjutnya untuk keterampilan konseptual kepala sekolah yang lebih mengarah kepada pelaksanaan program, peneliti lebih memfokuskan untuk mencari data dari tenaga pendidik dan tenaga kependidikan dengan asumsi bahwa tentunya tenaga pendidik dan tenaga kependidikan dalam menjalankan tanggung jawab tugas dan fungsinya tidak jauh dari program pendidikan karakter yang diinginkan oleh sekolah. Hasil penelitian di lapangan menunjukan pemahaman yang mendalam tentang penugasan tenaga pendidik dan kependidikan untuk mengawal pendidikan karakter tercermin dari bagaimana mereka memandang dan memperlakukan peserta didik sehingga menurut pendapat peneliti hal tersebut menunjukan bahwa kepala sekolah terampil dalam memberikan pengaruh konsep program pendidikan karakter sekolah kepada guru.

Hasil penelitian di lapangan lainnya menunjukan bahwa kepala sekolah SD AlAzhar Kelapa Gading Surabaya memiliki pandangan dan penilaian dalam menciptakan budaya lingkungan sekolah yang mendukung terlaksananya pendidikan karakter bagi peserta didik dan juga kepala sekolah memiliki pandangan ke depan akan apa yang dibutuhkan peserta didik untuk kedepannya, dan juga kepala sekolah dan guru dalam wawancara yang dilakukan 
telah memiliki kesamaan pandagan akan kekurangan programyang mesti harus terus menerus diperbaiki. Hal tersebut sesuai dengan pendapat Danim (2010: 73) yang menyebutkan bahwa keterampilan konseptual adalah kecakapan untuk memformulasikan pikiran, memahami teoriteori, melakukan aplikasi, melihat kecenderungan berdasarkan kemampuan toritis dan yang dibutuhkan di dunia kerja.

\section{Keterampilan Teknis Kepala Sekolah dalam Implementasi Pendidikan Karakter}

Penemuan penelitian di lapangan menunjukan bahwa dalam melaksanakan program pendidikan karakter, kepala sekolah SD Al-Azhar Kelapa Gading Surabaya selalu memberikan pembimbingan dalam memberikan tugas tambahan dalam program menanamkan pendidikan karakter kepada peserta didik. Perilaku kepala sekolah tersebut sesuai dengan teori keterampilan teknis yang dikemukakan oleh Sutisna (Muslim, 2016: 126) yaitu “... membantu dan membimbing pegawai dalam upaya perbaikan mutu kerja pegawai dan membantu pegawai dalam mendiagnosa kesulitan yang dihadapi pegawai".

Perilaku kepala sekolah lainnya yang menunjukan keterampilan teknis lainnya ialah saat kepala sekolah berperan sebagai supervisor guru, meskipun telah menggunakan CCTV sebagai media supervise dan bentuk kontrol rutin, kepala sekolah SD Al-Azhar Kelapa Gading Surabaya juga melakukan supervisi dengan mengunjungi kelas sebagai bentuk kontrol dalam pelaksanaan pembelajaran.

Kontrol rutin baik menggunakan media teknologi maupun secara manual akan dapat meningkatkan mutu sebuah program sekolah. Hal ini sesuai dengan pendapat Edet (2015) yaitu keberhasilan setiap sistem pendidikan bergantung pada rencana yang tepat, hal ini dapat dicapai melalui kepala sekolah dalam melakukan manajemen control terhadap pemeliharaan dan peningkatan sistem pendidikan. Control yang berkualitas yaitu dengan melakukan pengawasan rutin dan secara terus menerus. Spendapat dengan pendapat tersebut, Faisal (2012: 39) juga menyatakan pendapat yang sama terkait keterampilan teknis kepala sekolah yang harus menguasai pengetahuan tentang metode, proses, prosedur dan teknik untuk melaksanakan kegiatan khusus dan kemampuan untuk memanfaatkan serta mendayagunakan sarana, peralatan yang diperlukan dalam mendukung kegiatan yang bersifat khusus tersebut yang dalam penelitian ini ialah keterampilan teknis kepala sekolah dalam memanfaatkan sumberdaya sekolah untuk pengawasan program.

Hasil temuan penelitian juga menunjukan temuan kegiatan teknis kepala sekolah yang lain seperti kepala sekolah SD Al-Azhar Kelapa Gading Surabaya mengadakan pertemuan rutin untuk pengembangan mutu maupun sosialisasi program sekolah baik bagi guru, staff, maupun wali murid, memberikan kebebasan guru dalam melakukan inovasi dalam konsep pendidikan karkater Al-Azhar Kelapa Gading, dan kepala sekolah melakukan pelaporan sebagai tugas pokok dan fungsi sebagai kepala sekolah.

Metode tersebut sama halnya dengan yang diungkapkan Handoko (Usman, 2011: 146) yang menjabarkan kegiatan fungsi pengorganisasian sebagai keterampilan teknik sebagai berikut: 1) penentuan sumber daya dan kegiatan, 2) proses perancangan dan pengembangan kea rah tujuan, 3) penugasan tanggung jawab tertentu, 4) pendelagasian wewenang.

\section{Keterampilan Hubungan Manusia kepala sekolah SD Al-Azhar Kelapa Gading Surabaya}

Keterampilan kepala sekolah SD AlAzhar Kelapa Gading Surabaya dalam bergaul dan berkomunikasi telah sesuai dengan pendapat Danim (2010: 72) yang menjelaskan bahwa keterampilan hubungan manusia adalah keterampilan untuk menempatkan diri di dalam kelompok kerja dan menjalin komunikasi yang mampu menciptakan kepuasan kedua belah pihak. Hal yang sama juga diungkapkan Faisal (2012: 39) dalam penjelasannya tentang kemampuan berkomunikasi secara jelas dan efektif sehingga mampu menciptakan kerjasama yang efektif, kooperatif, praktis, dan diplomatis.

Keterampilan humanistik kepala sekolah SD Al-Azhar Kelapa Gading Surabaya ini juga senada dengan pendapat Wahyudi 
(Utami: 2014) yang juga menjelaskan hal yang sama bahwasanya kepala sekolah dalam berkomunikasi harus memiliki kemampuan diantaranya: “... kepala sekolah harus memberikan kesempatan kepada guru untuk mengemukakan pendapat sehingga tercipta komunikasi dua arah dan bersikanp terbuka tidak memaksakan kehendak dan menciptkan suasana demokratis dan persahabatan (kolegalitas)...".

Maka dari itu, melihat adanya kesesuaian kenyataan di lapangan dan pendapat di atas, maka dapat dikatakan kepala sekolah SD Al-Azhar Kelapa Gading Surabaya cukup terampil dalam melakukan komunikasi dengan bawahan di lingkungan sekolah. Adapun dengan lingkungan di luar sekolah, seperti dengan orang tua atau wali murid, telah dibentuk kerjasama berupa adanya organisasi pengawas yang berisi orang tua siswa yang bertugas mengawasi program-program sekolah. bentuk kolaborasi sekolah dengan tenaga pendidikan dan masyarakat sesuai dengan salah satu poin tentang kemampuan kepala sekolah yang dikatakan Mulyasa (2003:184) yaitu "kemampuan berkolaborasi dengan guru/pendidik dan masyarakat sekitar sekolah".

Peran serta masyarakat dalam organisasi yang mengawasi sekolah tersebut sesuai dengan UU No 20 tahun 2003 tetang sistem pendidikan nasional, pasal 54 yang menyebutkan peran serta masyarakat dalam pendidikan meliputi peran serta perorangan, kelompok, organisasi profesi, pengusaha dan organisasi kemasyarakatan dalam penyelenggaraan dan pengendalian mutu pelayanan pendidikan.

Keterampilan dalam memotivasi juga menunjukan ciri salah satu keterampilan hubungan manusia oleh kepala sekolah. hasil penelitian di lapangan menunjukan bahwa kepala sekolah memberikan motivasi secara verbal dengan memberikan kata-kata penggugah semangat pada saat pertemuan, maupun secara keaktifan kepala sekolah dengan memberikan contoh-contoh penyelesaian pekerjaan yang baik terlebih dahulu serta pemberian reward di luar tunjangan gaji dan kenaikan pangkat bagi individu maupun kelompok tenaga pendidikan dan kependidikan yang mempunyai prestasi, pengabdian, dll.
Bentuk motivasi yang diberikan kepala sekolah tentunya menumbuhkan rasa aman dan nyaman bagi tenaga kependidikan maupun tenaga pendidik, cerminan rasa aman dan nyaman dalam bekerja, lalu adanya keterbukaan antara pimpinan dan bawahan, dan adanya penghargaan tersebut sesuai dengan cerminan perilaku keterampilan hubungan manusia yang disebutkan Danim (2010: 73) yaitu: 1) Keterampilan menempatkan diri dalam kelompok, 2) keterampilan menciptakan kepuasan pada bawahan, 3) keterampilan bersikap terbuka terhadap kelompok kerja, 4) kemampuan mengambil hati melalui keramahan, 5) prnghargaan terhadap nilai, 6) pemerataan tugas dan tanggung jawab, dan 7) beritikad baik, adil, menghormati dan menghargai orang lain.

\section{SARAN}

Berdasarkan penelitian keterampilan manajerial kepala sekolah dalam program pendidikan karakter di SD Al-Azhar Kelapa Gading Surabaya, maka dipaparkansaran saran sebagai berikut:

a. Untuk menghadapi perkembangan ilmu pengetahuan dan teknologi yang semakin pesat sudah pasti dibutuhkan tenaga terampil baik tenaga pendidik maupun tenaga kependidikan agar dapat mengimbangi pengetahuan akan karakter apa saja yang dibuthkan peserta didik dalam menghadapi perkembangan zaman. Pelatihan keterampilan tersebut dapat juga diperoleh secara otodidak melalui perilaku pimpinan lembaga maupun dengan mengikutkan guru dalam pelatihan mengajar di tingkat nasional maupun internasional.

b. Untuk selanjutnya penulis harapkan kepala sekolah tidak cepat merasa puas dan mampu menularkan keterampilan dan ilmunya kepada tenaga pendidik maupun tenaga kependidikan. Karena, bukan tidak mungkin kelak mereka menjadikan kepala sekolah SD Al-Azhar Kelapa Gading Surabaya sekarang sebagai panutannya di masa yang akan datang.

c. Demi kelangsungan penanaman kebiasaan baik yang ada di sekolah maka ada baiknya orang tua juga turut serta mengawal pendidikan karakter 
anak di lingkungan rumah. Sehingga akan terbentuk sinergi karakter antara rumah dan sekolah.

d. Hasil penelitian ini dapat digunakan rujukan dalam mengkaji lebih lanjut masalah yang berkaitan dengan keterampilan manajerial kepala sekolah dalam menjalankan roda organisasi pendidikan maupun program-program pendidikan. Dapat juga dijadikan bahan pertimbangan bagi instansi terkait yang akan membuat rekomendasi model keterampilan manajerial kepala sekolah.

\section{DAFTAR RUJUKAN}

Bungin, Burhan. (2009). Analisis data penelitian kualitatif. Jakarta: Rajawali Pers

Creswell, John W. (2012). Research design. Pendekatan kualitatif, kuantitatif dan mixed. Yogyakarta: Pustaka Pelajar.

Danim, Sudarwan. (2002). Inovasi Pendidikan dalam upaya peningkatan profesi tenaga kependidikan. Bandung: Pustaka Setia

Danim, Sudarwan. (2010). Kepemimpinan Pendidikan. Bandung: Alfabeta

Edet, Aniefok Oswald dkk. (2015). Transforming Nigerian Youth leadership capacities in secondary school through principals managerial role effectiveness. World journal of education. Vol 5 No 5

Handoko, Hani T. (2001). Manajemen. Yogyakarta: BPFE

Lickona, Thomas. (2013). Pendidikan karakter, panduan lengkap mendidik siswa menjadi pintar dan baik. Bandung: Nusa Media

Mulyasa. (2003). Menjadi kepala sekolah professional. Bandung: Remaja Rosdakarya

Muslim, Hanafi. (2015). Tesis. Keterampilan manajerial kepala sekolah dalam meningkatkan kompetensi pedagogik guru di MAN Sampang. Universitas Negeri Surabaya.
Mustari, Mohamad. (2014). Nilai karakter, refleksi untuk pendidikan. PT Rajagrafindo Persada. Jakarta.

Peraturan menteri pendidikan Nasional Nomor 13 Tahun 2007.

Pidarta, Made. (2011). Manajemen Pendidikan Indonesia. Jakarta; PT Bina Aksara.

Rohman, Muhammad. \& Amri, Sofan. (2012). Manajemen pendidikan: analisis dan solusi terhadap kinerja manajemen kelas dan strategi pengajaran yang efektif. Jakarta. PT Prestasi Pustakarya.

Samani, Muchlas \& Hariyanto. (2011). Pendidikan karakter. Bandung; PT Remaja Rosdakarya.

Wahyudi. (2009). Kepemimpinan kepala skeolah dalam organisasi pembelajar. Bandung: Alfabeta.

Faisal, Adi Anwar, (2012). Skripsi. Pengaruh kemampuan manajerial kepala sekolah dasar negeri terhadap kinerja guru seKecamatan Kota Gede. Yogyakarta: UNY. 